\title{
Influence of Thicknesses of Smear Layer on the Transdentinal Cytotoxicity and Bond Strength of a Resin-Modified Glass-Ionomer Cement
}

\author{
Adriano Augusto Melo de MENDONÇA ${ }^{1}$ \\ Camila Fávero de OLIVEIRA ${ }^{2}$ \\ Josimeri HEBLING ${ }^{2}$ \\ Carlos Alberto de SOUZA COSTA ${ }^{3}$ \\ ${ }^{1}$ Department of Restorative Dentistry, Araraquara Dental School, \\ UNESP - Univ Estadual Paulista, Araraquara, SP, Brazil \\ ${ }^{2}$ Department of Orthodontics and Pediatric Dentistry, Araraquara Dental School, \\ UNESP - Univ Estadual Paulista, Araraquara, SP, Brazil \\ ${ }^{3}$ Department of Physiology and Pathology, Araraquara Dental School, \\ UNESP - Univ Estadual Paulista, Araraquara, SP, Brazil
}

\begin{abstract}
This study evaluated the transdentinal cytotoxicity (TC) and the bond strength (BS) of a resin-modified glass-ionomer cement (RMGIC) applied to dentin covered with smear layer (SL) of different thicknesses. Forty dentin discs had thick (TSL) or thin (THSL) smear layer created on their occlusal side. In artificial pulp chambers, MDPC-23 cells were seeded on the pulpal side of the dentin discs and divided into five groups: G1TC: no treatment (control); G2TC: TSL + RMGIC; G3TC: THSL + RMGIC; G4TC: TSL removal + RMGIC; G5TC: THSL removal + RMGIC. After 24 h, cell metabolism and morphology were evaluated by the methyltetrazolium (MTT) assay and by scanning electron microscopy (SEM), respectively. For BS, the following groups were determined: G1BS: TSL removal + RMGIC; G2BS: THSL removal + RMGIC; G3BS: TSL + RMGIC; G4BS: THSL + RMGIC. Shear bond strength was tested to failure in a mechanical testing machine MTS $(0.5 \mathrm{~mm} / \mathrm{min})$. Statistically significant difference was observed only between the control and experimental groups (Kruskal-Wallis, $\mathrm{p}<0.05$ ). The metabolic activity of the viable MDPC-23 cells in G2TC, G3TC, G4TC and G5TC decreased by $54.85 \%, 60.79 \%, 64.12 \%$ and $62.51 \%$, respectively. Mean shear bond strength values for G1BS, G2BS, G3BS and G4BS were 7.5, 7.4, 6.4 and 6.7 MPa, respectively, without significant difference among them (ANOVA, $p>0.05$ ). RMGIC presented moderate transdentinal cytotoxic effects. Maintenance or removal of smear layer did not affect the bond strength of RMGIC to dentin substrate.
\end{abstract}

Key Words: cell culture, smear layer, shear strength.

\section{INTRODUCTION}

Resin-modified glass-ionomer cements (RMGICs) were developed from the combination of conventional GIC formulation with polymerizable hydrophilic monomers of resin-based materials (1). These dental materials have been widely used as cavity liners and bases as well as for restoration of cavities with different depths where a biological seal and cariostatic action are needed, with excellent clinical outcomes (2).

It has been demonstrated that RMGICs present the advantageous property of adhering to dentin by means of a physicochemical interaction without prior treatment (1). However, studies have reported improvements in the bond strength (BS) of these materials to dentin after surface conditioning with various solutions $(1,3)$. The aim of conditioning is to remove contaminants and the smear layer that is usually formed during cavity preparation, which may interfere in the bonding of RMGICs to dental tissues (4). Depending on characteristics such as roughness, adherence and thickness, the presence of smear layer can affect negatively the bonding of restorative materials $(4,5)$. In addition, residual bacteria and their byproducts

Correspondence: Prof. Dr. Carlos Alberto de Souza Costa, Departamento de Fisiologia e Patologia, Faculdade de Odontologia de Araraquara, UNESP, Rua Humaitá, 1680, Centro, 14.801-903 Araraquara, SP, Brasil. Tel: +55-16-3301-6477. Fax: +55-16-3301-6488. e-mail: casouzac@foar.unesp.br 
harbored in the smear layer may cause pulpal damage (6). Therefore, removal of smear layer and smear plugs with chelating agents or conditioners without altering dentin morphology can be considered an effective clinical step to improve the interaction between liners and dentin.

Some studies have shown that clinically acceptable BSs of resin-based materials to dentin are obtained after smear layer removal with ethylenediaminetetraacetic acid (EDTA) $(7,8)$. However, the use of dentin conditioners in deep cavities can increase dentin permeability, allowing the outward dentin fluid movement from the dental pulp. The dentin fluid can interfere with RMGIC polymerization from which unreacted resin monomers and other components may leach and diffuse through the dentinal tubules to reach the pulp space (9). Therefore, the mechanical and biological properties of RMGICs applied to dentin covered or not with smear layers of different thicknesses should be investigated. Therefore, the purpose of this study was to evaluate the possible transdentinal cytotoxic effects and the shear BS of the RMGIC Vitrebond ${ }^{\mathrm{TM}}$ applied to dentin substrate covered or not with smear layers of different thicknesses.

\section{MATERIAL AND METHODS}

Eighty sound human third molars were obtained from the Human Tooth Bank of Araraquara Dental School, UNESP - Univ Estadual Paulista, Brazil, after approval of the research project by the institutional Ethics Committee (Protocol \#15/07).

\section{Permeability of Dentin Discs}

Forty teeth were used for analysis of the transdentinal cytotoxicity (TC). Using a precision cutting machine (Isomet 1000; Buehler Ltd., Lake Bluf, IL, USA) with a water-cooled diamond saw (Diamond Wafering Blade \#11-4254; Buehler Ltd.), 0.4-mm-thick dentin discs were cut transversally from the mid-coronal region of teeth. The smear layer produced on both sides of the dentin discs during sectioning was removed by application of $50 \mu \mathrm{L}$ of $0.5 \mathrm{M}$ EDTA $(\mathrm{pH}=7.2)$ for 60 $\mathrm{s}$, followed by copious distilled water rinsing. The hydraulic conductance $\left(\mathrm{Lp} ; \mathrm{L} / \mathrm{cm}^{2} / \mathrm{min} / \mathrm{cm} \mathrm{H}_{2} \mathrm{O}\right.$ ) of each dentin disc was determined using a $180-\mathrm{cm}$ manometer column filled with water, as described in a previous study (10). This procedure was carried out in order to reduce the interference of dentin permeability due to anatomic variations in the dentinal structure of each tooth. The hydraulic conductance data were analyzed by the Kruskal-Wallis test, which demonstrated homogenous distribution of dentin discs among the control and experimental groups $(\mathrm{p}>0.05)$.

\section{Production of Smear Layer}

The occlusal side of the dentin discs was polished with wet 180 - and 600-grit silicon carbide (SiC) paper for production of standardized thick smear layer (TSL) and thin smear layer (THSL), respectively $(5,11)$.

A two-compartment artificial pulp chamber (APC) was used to analyze the transdentinal cytotoxicity of the RMGIC (Fig. 1). Five groups $(n=8)$ were formed according to the smear layer thickness and its maintenance or removal from the occlusal side of the discs: G1TC: no treatment (control); G2TC: TSL + RMGIC; G3TC: THSL + RMGIC; G4TC: TSL removal (EDTA) + RMGIC; G5TC: THSL removal (EDTA) + RMGIC. In G4TC and G5TC, 0.5 M EDTA, pH=7.2, was applied during $30 \mathrm{~s}$ for smear layer removal followed by copious rinsing with deionized water (8). The APCs with the dentin discs in position were immersed in glass receptacles containing deionized water and were autoclaved at $120^{\circ} \mathrm{C}$ for $15 \mathrm{~min}$.

\section{MDPC-23 Cell Culture}

Immortalized cells of the MDPC-23 cell line were defrosted and cultured in Dulbecco's Modified Eagle's Medium (DMEM; Sigma Chemical Co., St. Louis, MO, USA) supplemented with $10 \%$ fetal bovine serum (FBS; Gibco, Grand Island, NY, USA), with

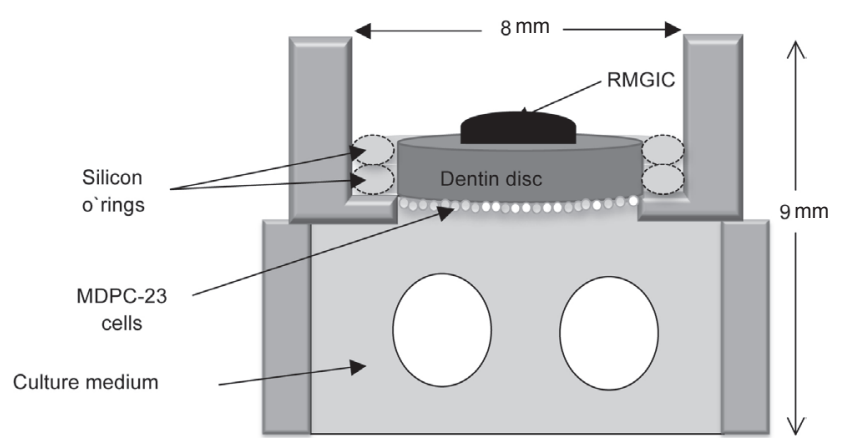

Figure 1. Illustration of an artificial pulp chamber (APC) where a dentin disc was positioned between two silicon o'rings. The pulp cells were seeded on the pulpal side of the dentin disc, being in contact with culture medium. The RMGIC was applied on occlusal side of the disc. 
$100 \mathrm{IU} / \mathrm{mL}$ penicillin, $100 \mu \mathrm{g} / \mathrm{mL}$ streptomycin and 2 $\mathrm{mM} / \mathrm{L}$ glutamine (Gibco, Grand Island, NY, USA) in an humidified incubator with $5 \% \mathrm{CO}_{2}$ and $95 \%$ air at $37^{\circ} \mathrm{C}$ (Isotemp; Fisher Scientific, Pittsburgh, PA, USA). The MDPC-23 cells were sub-cultured every 3 days until reaching a sufficient number of cells to perform the study.

\section{Seeding of MDPC-23 Cells on Dentin Discs}

After autoclaving, the APCs with the dentin discs were placed in the wells of sterile 24-well plates (Costar Corp., Cambridge, MA, USA) with the pulpal side of the discs turned upwards. The MDPC-23 cells $(50,000$ cells $/ \mathrm{cm}^{2}$ ) were seeded on the pulpal dentin surface and the plates containing the APCs were incubated at $37^{\circ} \mathrm{C}$ in a humidified incubator with $5 \% \mathrm{CO}_{2}$ and $95 \%$ air atmosphere for $48 \mathrm{~h}$. After this period, the APCs were inverted in the wells in such a way that the pulpal side of the discs was turned downwards so that the MDPC23 cells attached to the dentin could be in contact with the culture medium. On the other hand, the occlusal side of the discs was maintained upwards to allow the subsequent application of the RMGIC Vitrebond.

The occlusal side of the dentin discs was gently rinsed with sterile PBS and dried with sterile small cotton pellets. The RMGIC was mixed according to the manufacturer's instructions and then applied directly on the occlusal side of the discs in a single increment (1 mm-thick). The material was photoactivated for 30 $\mathrm{s}$ with a halogen light-curing unit (Curing Light 3000 XL; 3M ESPE, St Paul, MN, USA) with the light guide tip at a $3 \mathrm{~mm}$ distance from the material surface. After 24-h incubation at $37^{\circ} \mathrm{C}$ with $5 \% \mathrm{CO}_{2}$ and $95 \%$ air, the discs were carefully removed from the APCs and the metabolic activity and morphology of the viable cells was evaluated.

\section{Analysis of Cell Metabolism (MTT Assay)}

In each group, 6 out of 8 specimens were used for analysis of cell metabolism by the cytochemical demonstration of succinic dehydrogenase (SDH) activity, which is a measure of the mitochondrial respiration of the cells, employing the methyl tetrazolium (MTT) assay.

For the MTT assay, the extracts in contact with the cells were replaced by $900 \mu \mathrm{L}$ of plain DMEM plus $100 \mu \mathrm{L}$ of the MTT solution ( $5 \mathrm{mg} / \mathrm{mL}$ sterile phosphate buffered saline - PBS). The cells were incubated at $37^{\circ} \mathrm{C}$ for $4 \mathrm{~h}$. Thereafter, the culture medium with the MTT solution was aspirated and replaced by 600 $\mu \mathrm{L}$ of acidified isopropanol solution $(0.04 \mathrm{~N} \mathrm{HCl})$ in each well to dissolve the blue crystals of formazan in the viable cells. Three $100 \mu \mathrm{L}$ aliquots of each well were transferred to the wells of 96-well plates. Cell viability was evaluated by spectrophotometry as being proportional to the absorbance measured at $570 \mathrm{~nm}$ wavelength with an ELISA plate reader (Multiskan; Ascent 354, Lab systems CE, Les Ulis, France). The values obtained from the three aliquots were averaged to provide a single value for each well. The means were calculated for the groups and presented as percentages that represented the inhibitory effect of the mitochondrial activity of the cells by the RMGIC components.

\section{Analysis of Cell Morphology by Scanning Electron Microscopy (SEM)}

The two other representative specimens of the control and experimental groups were used for analysis of cell morphology by SEM. The discs removed from the APCs were immediately immersed in $2.5 \%$ glutaraldehyde solution for $120 \mathrm{~min}$ and post-fixed with $1 \%$ osmium tetroxide for $60 \mathrm{~min}$. The discs with the odontoblast-like cells adhered to dentin surface were dehydrated in an ascending ethanol series (30, $50,70,90$ and $100 \%$ ) and immersed in $250 \mu \mathrm{L}$ of 1,1,1,3,3,3-hexamethyldisilazane (HMDS; Acros Organics, Springfield, NJ, USA) for $60 \mathrm{~min}$ at room temperature. The specimens were stored in a desiccator for $24 \mathrm{~h}$, mounted on metallic stubs and sputter-coated with gold. The cells that remained adhered to the dentin surface had their morphology examined with a scanning electron microscope (JEOL-JMS-T33A; JEOL-USA Inc., Peabody, MA, USA).

\section{Shear Bond Strength Test}

Forty teeth were used for evaluation of the shear BS of the RMGIC to dentin covered or not with smear layers of different thicknesses. In the precision cutting machine (Isomet 1000; Buehler Ltd.), the teeth had their occlusal surface sectioned transversally $2 \mathrm{~mm}$ below the central occlusal groove to obtain a flat mid-coronal dentin surface. The specimens were analyzed under a stereomicroscope (Model SZX7; Olympus, São Paulo, SP, Brazil) at $\times 30$ magnification to confirm the absence of enamel islets. 
The teeth had their roots embedded in chemically activated acrylic resin (Clássico Artigos Odontológicos Ltda., São Paulo, SP, Brazil) using PVC cylinders (Tigre, Rio Claro, SP, Brazil) as molds. Then the dentin surface was polished in a polishing machine (Buehler Ltd.) at 200 rpm for $10 \mathrm{~s}$ with wet 180- and 600-grit $\mathrm{SiC}$ paper for production of thick and thin smear layers, respectively. Polyethylene tubes (4 mm diameter and $1.5 \mathrm{~mm}$ high) were positioned on dentin surface and filled with the RMGIC in a single increment using a Centrix injector (Centrix Inc., Shelton, CT, USA).

The following groups were established after RMGIC application on smear-covered dentin surface: G1BS: TSL + EDTA + RMGIC; G2BS: THSL + EDTA + RMGIC; G3BS: TSL + RMGIC; G4BS: THSL + RMGIC. All the procedures carried out on dentin in the presence or absence of smear layer are demonstrated in Table 1.

After 24 -h storage in distilled water at $37^{\circ} \mathrm{C}$, the specimens were loaded in shear strength using a knifeedge blade in a mechanical testing machine (MTS 810; MTS Systems Corporation, Minneapolis, MN, USA) running at a crosshead speed of $0.5 \mathrm{~mm} / \mathrm{min}$ with $1 \mathrm{kN}$ load cell until bond failure. BS values were expressed in $\mathrm{MPa}$.

Table 1. Summary of shear bond strength groups according to the procedures carried out on dentin in presence or absent of smear layer.

\begin{tabular}{lc}
\hline Group (n=10) & Procedure \\
\hline $\begin{array}{l}\text { TSL + EDTA + RMGIC } \\
\text { (G1BS) }\end{array}$ & $\begin{array}{c}\text { Application of 0.5 M EDTA } \\
\text { on dentin for } 30 \mathrm{~s} \text { followed } \\
\text { by abundant water rinsing } \\
\text { with distilled water for } 10 \mathrm{~s}\end{array}$ \\
& $\begin{array}{c}\text { Application of } 0.5 \text { M EDTA } \\
\text { on dentin for } 30 \mathrm{~s} \text { followed } \\
\text { by abundant water rinsing } \\
\text { THSL + EDTA + RMGIC } \\
\text { (G2BS) }\end{array}$ \\
$\begin{array}{l}\text { with distilled water for } 10 \mathrm{~s} \\
\text { TSL + RMGIC }\end{array}$ & $\begin{array}{c}\text { Application of Vitrebond } \\
\text { and exposure to visible light } \\
\text { for } 30 \mathrm{~s} .\end{array}$ \\
$\begin{array}{l}\text { THSL }+ \text { RMGIC } \\
\text { (G4BS) }\end{array}$ & $\begin{array}{c}\text { Application of Vitrebond } \\
\text { and exposure to visible light }\end{array}$ \\
\hline
\end{tabular}

RMGIC: Resin-modified glass-ionomer cement. TSL: Thick smear layer. THSL: Thin smear layer.

\section{Statistical Analysis}

As the data obtained from the MTT assay had a non-normal distribution, the Kruskal-Wallis and MannWhitney non-parametric tests were used for statistical analysis of the results. The absolute values of SDH production were converted into percentage considering the control group as presenting $100 \%$ of cell metabolism.

BS data had normal distribution and thus oneway ANOVA and Tukey's test were used for statistical analysis of the results. A significance level of 5\% was set for all analyses.

\section{RESULTS}

\section{Transdentinal Cytotoxicity}

Analysis of cell metabolism (MTT assay): The descriptive data (medians and interquartile intervals) obtained from the analysis of hydraulic conductance and MTT assay for the control and experimental groups are shown in Table 2. G2TC, G3TC, G4TC and G5TC differed significantly from G1TC (control) $(\mathrm{p}<0.05)$. The groups G4TC and G5TC presented the lowest metabolic activity followed by the groups in which smear layer was not removed (G2TC and G3TC); however, pairwise comparisons did not show statistically significant differences ( $p>0.05$ ) among the experimental groups. When RMGIC was applied on dentin discs covered with

Table 2. Medians of hydraulic conductance (HC) and MTT assay in the different groups.

\begin{tabular}{lcc}
\hline Group (n=6) & HC & MTT assay $(\mathrm{P} 25-\mathrm{P} 75)$ \\
\hline Control (G1TC) & $0.0024 \mathrm{~A}$ & $0.1803(0.1720-0.1885)^{\mathrm{a}}$ \\
$\begin{array}{l}\text { TSL + RMGIC } \\
\text { (G2TC) }\end{array}$ & $0.0021 \mathrm{~A}$ & $0.0814(0.655-0.1053)^{\mathrm{b}}$ \\
$\begin{array}{l}\text { THSL + RMGIC } \\
\text { (G3TC) }\end{array}$ & $0.0025 \mathrm{~A}$ & $0.0707(0.649-0.772)^{\mathrm{b}}$ \\
$\begin{array}{l}\text { TSL removal/ EDTA } \\
+ \text { RMGIC (G4TC) }\end{array}$ & $0.0021 \mathrm{~A}$ & $0.0647(0.599-0.691)^{\mathrm{b}}$ \\
$\begin{array}{l}\text { TSL removal/ EDTA } \\
+ \text { RMGIC (G5TC) }\end{array}$ & $0.0027 \mathrm{~A}$ & $0.0676(0.623-0.727)^{\mathrm{b}}$ \\
\hline
\end{tabular}

RMGIC: Resin-modified glass-ionomer cement. TSL: Thick smear layer. THSL: Thin smear layer. Groups with same letters represent no statistically difference (Mann-Whitney, $\mathrm{p}<0.05$ ). 
TSL and THSL, the cell metabolic activity decreased by $54.85 \%$ and $60.79 \%$, respectively. When TSL and THSL were removed, the depression of cell metabolism raised to $64.12 \%$ and $62.51 \%$, respectively.

SEM analysis: In G1TC (control), a large number of cells with wide cytoplasm and remarkable mitotic activity remained adhered to the pulp side of the dentin discs (Fig. 2A). On the other hand, only few round or spindle-shaped cells were adhered to the dentin substrate in group G2TC (Fig. 2B). Similar characteristics were observed for the cells in the groups in which THSLwas maintained on the occlusal side of the discs (G3TC) (Fig. 2C). When TSL was removed (G4TC), the MDPC23 cells showed similar morphology to that observed in G3TC, with large exposed dentin areas due to the detachment of dead cells from the dentinal substrate (Fig. 2D). In G5TC, extensive cell-free dentin areas were also observed with residual fragments of cytoplasmic processes of lethally damaged cells that detached from disc surface (Fig. 2E).

\section{Shear Bond Strength Test}

The mean $\mathrm{BS}$ values (in $\mathrm{MPa}$ ) and standard deviations of Vitrebond to the smear-covered dentin treated or not with EDTA were as follows: G1BS (TSL + EDTA + RMGIC): 6.7 (2.0); G2BS (THSL + EDTA + RMGIC): 6.4 (1.3); G3BS (TSL + RMGIC): 7.4 (1.6); G4BS (THSL + RMGIC): 7.5 (2.1). No statistically significant differences $(p>0.05)$ were observed among the groups.

\section{DISCUSSION}

The immortalized cell line MDPC-23 has been widely used to evaluate potential toxic effects of dental materials or their individual components $(10,12,13)$. This immortalized cell line presents a similar phenotype to that of odontoblasts in vivo (14), which are organized in a monolayer that underlies the dentin in mammalian teeth. For this reason, the odontoblasts are the first cells to be damaged by potentially cytotoxic compounds leached from dental materials that diffuse through the dentinal tubules and reach the pulp space. In this sense, the MDPC-23 cell line was considered as adequate to be used in the present study to evaluate the transdentinal cytotoxicity of the RMGIC Vitrebond.

It has been demonstrated that Vitrebond is a
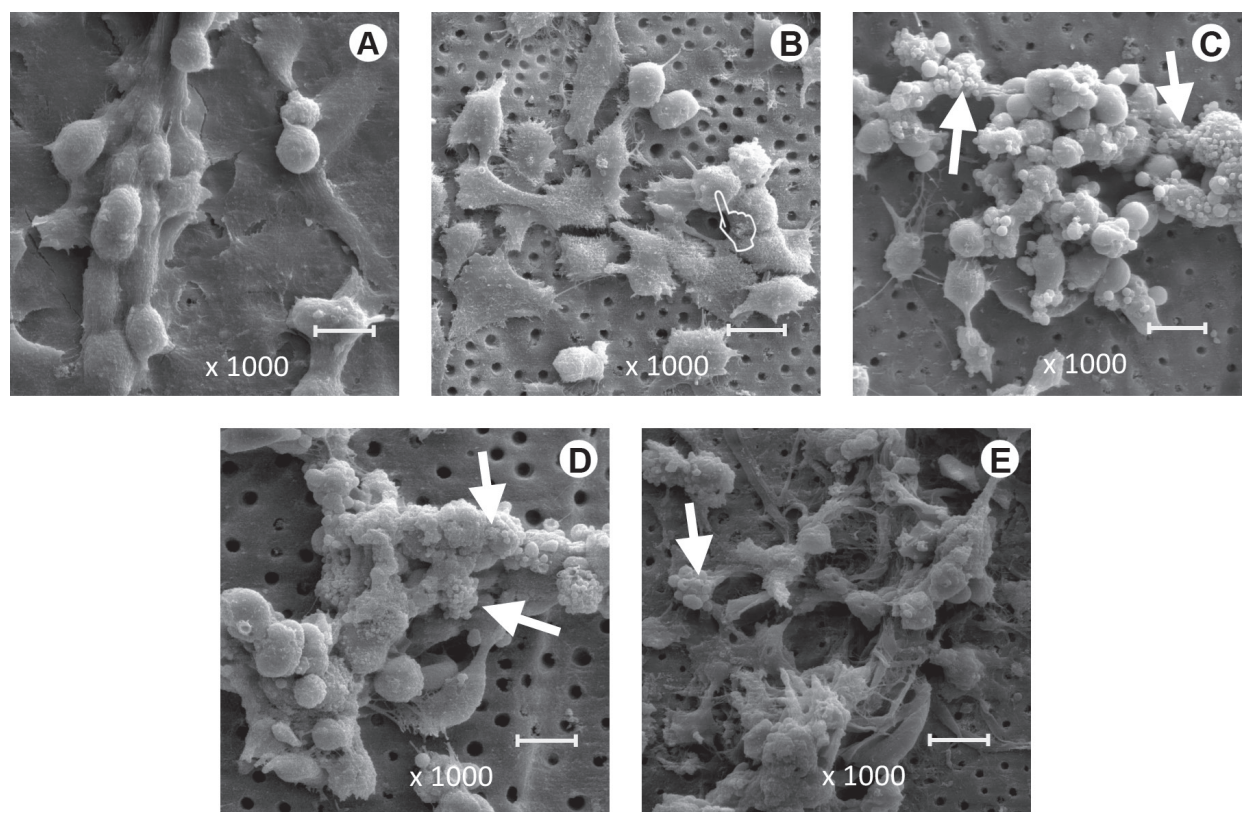

Figure 2. SEM images of MDPC-23 cells adhered to dentin discs in control and experimental groups. A: G1TC (Control): A number of MDPC-23 cells with large cytoplasm covering the dentinal substrate. B: G2TC (TSL + RMGIC): A few cells that remained on dentin exhibits reduced size, some of which present round shape (pointer). Observe that several dentin tubules are exposed. C: G3TC (THSL + RMGIC). D: G4TC (TSL removal with EDTA + RMGIC). E: G5TC (THSL removal with EDTA + RMGIC): In these three groups, a small number of MDPC-23 cells with round shape and granular membrane are observed on dentin substrate (arrows). SEM, Original magnification $\times 1,000$. 
biocompatible dental material when applied on the floor of deep cavities prepared in human teeth (15). In addition, this RMGIC presents great antibacterial activity against cariogenic bacteria (16) and so it was assumed that the direct contact of this material with contaminated dentin after caries removal would be favorable to the repair of the pulp-dentin complex. In the present study, thin and thick smear layers created on dentin surface were either removed or maintained prior to RMGIC application. Using the MTT assay, it was observed that cell metabolism decreased by around $60 \%$ in all experimental groups (Mann-Whitney, $\mathrm{p}>0.05$ ), which means that the RMGIC placed on smear-free or smear-covered 0.4-mm-thick dentin discs caused moderate transdentinal cytotoxic effects. These data are not in accordance with previous in vivo studies in which Vitrebond was applied as liner in very deep cavities (15). It is known that the concentration of residual components released from dental materials in culture medium causes toxic effects directly on cell cultures in vitro and it is not the same as the concentration that reaches pulp cells in vital teeth via transdentinal diffusion. However, the research protocol employed in the current in vitro study as well as in previous investigations may predict and compare the cytotoxic effects of different clinical procedures and dental materials $(10,17)$.

The application of EDTA on dentin substrate can yield adequate shear BS (7). In the present study, a 0.5 M EDTA solution ( $\mathrm{pH}=7.2)$ was applied on dentin for $30 \mathrm{~s}$. As this solution removes smear layer without causing morphological alterations on dentin substrate (8), it may be speculated that the lack of significant difference in cell metabolism between the groups where the smear layer was maintained (G2TC and G3TC) or removed (G4TC and G5TC) might be attributed to the presence of smear plugs sealing the tubule entrances. It is feasible to assume that a greater transdentinal diffusion of cytotoxic components could have occurred if the dentinal tubules had been exposed by removal of smear plugs. In addition, it has been shown that crystals resulting from the reaction between acidic component of RMGIC and dentin are deposited at tubule entrances (2), decreasing significantly the permeability. In this way, it may be speculated that the presence of these crystals at the tubule entrances may be responsible, at least in part, for the lack of statistically significant difference in the metabolic activity of the cells among the experimental groups.

The cytotoxic effects of RMGICs have been attributed to the organic components present in their resin matrix, such as HEMA $(18,19)$. Great amounts of this low-molecular-weight hydrophilic monomer (MW=130.1) can diffuse rapidly through the dentin tubules to reach the pulp space $(17,20)$. According to Bouillaguet et al. (20), HEMA has a dilution factor of 1,000-5,000 times across $0.5 \mathrm{~mm}$ of dentin under a 10 $\mathrm{cm} \mathrm{H}_{2} \mathrm{O}$ back-pressure. As a pure 50\% HEMA solution is equivalent to $4,000 \mathrm{mmol} / \mathrm{L}$, it may be speculated that for Vitrebond (20-25\% HEMA), 1,600-2,000 mmol/L of HEMA could reach the odontoblast-like cells with the lowest dilution factor. Especially for G2TC and G3TC, in which the smear layer was not removed with EDTA, this concentration can be even lower considering that Vitrebond is indicated for direct application on the smearcovered dentin, which reduces dentin permeability. However, in the present study, the SEM micrographs revealed large cell-free areas on dentin surface in all experimental groups. It may be assumed that cell death might have been caused by cement components other than HEMA. It has been reported that products of Vitrebond decomposition, such as diphenyliodonium chloride, are capable to cause severe toxic effects to cell cultures (19). Other chemicals released from Vitrebond, such as benzene chloride ( $\mathrm{MW}=107.5$ ), benzene iodide ( $\mathrm{MW}=199$ ) and benzene bromide ( $\mathrm{MW}=152$ ), might have intensified the cytopathic effects of this material. However, future studies are required to investigate the diffusion of these RMGIC components through the hard dental tissues.

In addition to the transdentinal cytotoxic effects of Vitrebond ${ }^{\mathrm{TM}}$, the present study also evaluated the shear BS of this RMGIC to dentin covered with thin and thick smear layers produced by polishing with 600 and 180 -grit $\mathrm{SiC}$ papers, respectively. It has been reported that dentin abraded with 600 -grit $\mathrm{SiC}$ paper presents overestimated BSs when compared with those obtained on dentin covered with clinically produced smear layers (4). However, 600-grit $\mathrm{SiC}$ has been employed to create an approximately 0.5 - $\mu \mathrm{m}$-thick smooth, uniform, compact smear layer (5). On the other hand, 180-grit $\mathrm{SiC}$ creates coarse, less consistent smear layers with thicknesses ranging from 0.7-3.3 $\mu \mathrm{m}$, which simulate the smear layers formed clinically with carbide burs (4). In the present study, BSs of Vitrebond to dentin covered with TSL (G3BS) and THSL (G4BS) were 7.4 MPa and 7.5 $\mathrm{MPa}$, respectively, without significant difference between the groups. It has been demonstrated that selfetch adhesives with moderate aggressiveness $(\mathrm{pH}=2.7)$ 
form thin hybrid layers (400-500 nm thick) when applied directly to dentin smear layer of different thicknesses without pretreatment (4). The liquid component of the Vitrebond, which contains polycarboxylic acid, has similar acidic $\mathrm{pH}(\mathrm{pH}=2.5)$. However, when the powder and liquid components of Vitrebond are mixed, the $\mathrm{pH}$ of the resulting cement increases to 3.6 (21). This higher $\mathrm{pH}$ value is probably ineffective in modifying TSL and THSL and demineralizing the subjacent dentin. This fact may be responsible for the lack of statistically significant difference between G3BS and G4BS.

In the attempt to increase BS of RMGICs to dentin, pretreatment (conditioning) of this substrate with various solutions has been suggested $(3,4)$. In the present study, smear layers of different thicknesses were removed by application of $0.5 \mathrm{M}$ EDTA for $30 \mathrm{~s}$. BSs of 6.4 and 6.7 MPa were obtained in G1BS (TSL removal) and G2BS (THSL removal), respectively. Despite the tendency for a decrease in the BS of Vitrebond to the smear-free dentin, no statistically significant difference was found among the four groups. Batista et al. (22) demonstrated that the dentin treated with EDTA is much rougher than the smear-covered dentin. This fact could add to the interlocking of Vitrebond to smear-free dentin and might explain the statistically similar BS values obtained in the groups. Another factor may also have contributed for the retention of the RMGIC to dentin. Chemical bonding is also a significant factor in the adhesion capacity of Vitrebond to dentin (23). This material is composed by a methacrylate-modified copolyalkenoic acid molecule, which participates in both the ionomeric reaction and the visible light activated methacrylate curing. Fouriertransformed infrared spectroscopy (FTIR) and X-ray photoelectron spectroscopy (XPS) data have shown that the carboxyl groups in this molecule form ionic carboxylate bonds to the calcium in hydroxyapatite (24). This interaction between Vitrebond and dentin gives rise to a poly(HEMA) hydrogel layer, named as "absorption" layer, which plays a key role in the BS of some RMGICs (25). It may be speculated that this type of "absorption" layer may have contributed, at least in part, for the lack of significant difference among the groups.

According to the methodologies employed in the present in vitro study, it may be concluded that the RMGIC Vitrebond caused transdentinal toxic effects to MDPC-23 cells when applied to smear-free dentin and dentin covered with both thin and thick smear layers. In addition, the maintenance or removal of smear layer with a 30 -s application of $0.5 \mathrm{M}$ EDTA did not affect the BS of this resin-based material to dentin substrate. Further studies are required to investigate different dentin conditioners and treatments that may improve the BS of RMGICs to dentin substrate without causing cytopathic effects to pulp cells.

\section{RESUMO}

Este estudo avaliou a citotoxicidade transdentinária (CT) e a resistência de união (RU) de um cimento de ionômero de vidro modificado por resina (CIVMR) aplicado sobre dentina coberta com smear layer (SL) de diferentes espessuras. Quarenta discos de dentina tiveram smear layer espessa (TSL) ou delgada (THSL) criadas sobre a superfície oclusal. Após terem sido posicionados em câmaras pulpares artificiais, os discos de dentina receberam células MDPC-23, as quais foram semeadas sobre a supefície pulpar. Assim, os seguintes grupos foram estabelecidos: G1TC: sem tratamento (controle); G2TC: TSL + CIVMR; G3TC: THSL + CIVMR; G4TC: remoção TSL + CIVRM; G5TC: remoção THSL + CIVMR. Após 24 h, o metabolismo e morfologia celular foram avaliados pelo ensaio de metiltetrazolium (MTT) e por microscopia eletrônica de varredura (MEV), respectivamente. Para BS, os seguintes grupos foram determinados: G1BS: remoção TSL + CIVRM; G2BS: remoção THSL + CIVRM; G3BS: TSL + CIVRM; G4BS: THSL + CIVMR. A resistência de união ao cisalhamento foi avaliada em uma máquina de ensaios mecânicos MTS $(0,5 \mathrm{~mm} / \mathrm{min})$. Diferença estatisticamente significativa foi observada apenas entre os grupos controle e experimentais (Kruskal-Wallis, $\mathrm{p}<0,05$ ). A redução da atividade metabólica das células MDPC-23 viáveis nos grupos G2TC, G3TC, G4TC e G5TC foi de 54,85\%; 60,79\%; 64,12\%; e 62,51\%, respectivamente. Os valores médios de resistência de união para G1BS, G2BS, G3BS e G4BS foram de 7,5; 7,4; 6,4; e 6,7 MPa, respectivamente, sem diferença significativa entre eles (ANOVA, $\mathrm{p}>0,05)$. O CIVMR avaliado neste estudo apresentou moderado efeito citotóxico transdentinário. A manutenção ou remoção da smear layer não afetou a resistência de união deste material resinoso ionomérico sobre a dentina.

\section{ACKNOWLEDGEMENTS}

The authors acknowledge Fundação de Amparo à Pesquisa do Estado de São Paulo: FAPESP (grant: \#2009/54215-7) and Conselho Nacional de Desenvolvimento Científico and Tecnológico: CNPq (grant: \#301291/2010-1) for the financial support.

\section{REFERENCES}

1. Sampaio PC, de Almeida Júnior AA, Francisconi LF, CasasApayco LC, Pereira JC, Wang L, Atta MT. Effect of conventional and resin-modified glass-ionomer liner on dentin adhesive interface of Class I cavity walls after thermocycling. Oper Dent 2011;36:403-412.

2. Titley KC, Smith DC, Chernecky R. SEM observations of the reactions of the components of a light-activated glass polyalkenoate (ionomer) cement on bovine dentine. J Dent 1996;24:411-416. 
3. El-Askary, Nassif MS, Fawzy AS. Shear bond strength of glassionomer adhesive to dentin: effect of smear layer thickness and different dentin conditioners. J Adhes Dent 2008;10:471-479.

4. Kenshima S, Reis A, Uceda-Gomez N, Tancredo L de L, Filho LE, Nogueira FN, Loguercio AD. Effect of smear layer thickness and $\mathrm{pH}$ of self-etching adhesive systems on the bond strength and gap formation to dentin. J Adhes Dent 2005;7:117-126.

5. Reis A, Grandi V, Carlotto L, Bortoli G, Patzlaff R, Rodrigues Accorinte ML, et al.. Effect of smear layer thickness and acidity of self-etching solutions on early and long-term bond strength to dentin. J Dent 2005;33:549-559.

6. Mjör IA. Dentin permeability: the basis for understanding pulp reactions and adhesive technology. Braz Dent J 2009;20:3-16.

7. Cederlund A, Jonsson B, Blomlof J. Shear strength after ethylenediaminetetraacetic acid conditioning of dentin. Acta Odontol Scand 2001;59:418-422.

8. Jacques P, Hebling J. Effect of dentin conditioners on the microtensile bond strength of a conventional and a self-etching primer adhesive system. Dent Mater 2005;21:103-109.

9. Galler K, Hiller KA, Ettl T, Schmalz G. Selective influence of dentin thickness upon cytotoxicity of dentin contacting materials. J Endod 2005;31:396-399.

10. Lanza CR, de Souza Costa CAS, Furlan M, Alécio A, Hebling J. Transdentinal diffusion and cytotoxicity of self-etching adhesive systems. Cell Biol Toxicol 2009;25:533-543.

11. Oliveira SS, Pugach MK, Hilton JF, Watanabe LG, Marshall SJ, Marshall GW, Jr. The influence of the dentin smear layer on adhesion: a self-etching primer vs. a total-etch system. Dent Mater 2003;19:758-767.

12. Coldebella CR, Ribeiro AP, Sacono NT, Trindade FZ, Hebling $\mathrm{J}$, Costa CAS. Indirect cytotoxicity of a $35 \%$ hydrogen peroxide bleaching gel on cultured odontoblast-like cells. Braz Dent J 2009;20:267-274.

13. de Lima Af, Lessa FC, Gasparoto Mancini MN, Hebling J, de Souza Costa CAS, Marchi GM. Cytotoxic effects of different concentrations of a carbamide peroxide bleaching gel on odontoblast-like cells MDPC-23. J Biomed Mater Res B Appl Biomater 2009;90:907-912.
14. Hanks CT, Sun ZL, Fang DN, Edwards CA, Wataha JC, Ritchie $\mathrm{HH}$, et al.. Cloned $3 \mathrm{~T} 6$ cell line from CD-1 mouse fetal molar dental papillae. Connect Tissue Res 1998;37:233-249.

15. Costa CAS, Giro EM, do Nascimento AB, Teixeira HM, Hebling J. Short-term evaluation of the pulpo-dentin complex response to a resin-modified glass-ionomer cement and a bonding agent applied in deep cavities. Dent Mater 2003;19:739-746.

16. Duque C, Negrini Tde C, Hebling J, Spolidorio DM. Inhibitory activity of glass-ionomer cements on cariogenic bacteria. Oper Dent 2005;30:636-640.

17. Cetinguc A, Olmez S, Vural N. HEMA diffusion from dentin bonding agents in young and old primary molars in vitro. Dent Mater 2007;23:302-307.

18. de Souza Costa CA, Hebling J, Garcia-Godoy F, Hanks CT. In vitro cytotoxicity of five glass-ionomer cements. Biomaterials 2003;24:3853-3858.

19. Geurtsen W, Spahl W, Leyhausen G. Residual monomer additive and release variability in cytotoxicity of light-curing glassionomer cements and compomers. J Dent Res 1998;77:2012-2019.

20. Bouillaguet S, Virgillito M, Wataha J, Ciucchi B, Holz J. The influence of dentine permeability on cytotoxicity of four dentine bonding systems, in vitro. J Oral Rehabil 1998;25:45-51.

21. Ben-Amar A, Liberman R, Apatowsky U, Pilo R. pH changes of glass-ionomer lining materials at various time intervals. J Oral Rehabil 1999;26:847-852.

22. Batista LH, Junior JG, Silva MF, Tonholo J. Atomic force microscopy of removal of dentin smear layers. Microsc Microanal 2007; 13:245-250.

23. Rusin RP, Agee K, Suchko M, Pashley DH. Effect of a new liner/ base on human dentin permeability. J Dent 2010;38:245-252.

24. Mitra SB, Lee CY, Bui HT, Tantbirojn D, Rusin RP. Long-term adhesion and mechanism of bonding of a paste-liquid resinmodified glass-ionomer. Dent Mater 2009;25:459-466.

25. Sidhu SK, Sherriff M, Watson TF. Failure of resin-modified glassionomers subjected to shear loading. J Dent 1999;27:373-381.

Received December 16, 2011 Accepted August 15, 2012 